УДК 616.366-003.7-06:616.3-009.819-072.1

DOI 10.11603/2414-4533.2016.3.6801

( ) М. М. ГАЛЕЙ, І. Я. ДЗЮБАНОВСЬКИЙ

ДВНЗ “Тернопільський державний медичний університет імені І. Я. Горбачевського”

Волинська обласна клінічна лікарня

\title{
Симультанні лапароскопічні операції у хворих на жовчнокам'яну хворобу та супутню хірургічну абдомінальну патологію
}

\author{
M. M. HALEY, I. YA. DZIUBANOVSKYI \\ I. Horbachevsky Ternopil State Medical University \\ Volyn Regional Clinical Hospital
}

\section{SIMULTANEOUS LAPAROSCOPIC SURGERIES IN PATIENTS WITH CHOLELITHIASIS AND CONCOMITANT SURGICAL ABDOMINAL PATHOLOGY}

\begin{abstract}
Проведено аналіз малоінвазивного хірургічного лікування хворих із жовчнокам'яною хворобою і супутніми хірургічними захворюваннями лікарні в період 2009-2015 pр. у відділенні інвазивних методів діагностики та лікування Волинської обласної клінічної лікарні. Встановлено зручну черговість симультанних операційних лапароскопічних втручань у хворих із ЖКХ. Віднайшли оптимальне стереометричне співвідношення робочих інструментів при виконанні симультанних лапароскопічних операційних втручань.

The analysis of minimally invasive surgical treatment of cholelithiasis and concomitant surgical diseases during the years 20092015 at the Department of Invasive Methods of Diagnosis and Treatment of Volyn Regional Hospital was conducted. The next, comfortable, sequence of simultaneous surgical laparoscopic procedures in patients with cholelithiasis was found. Optimal stereometric ratio of working tools when performing simultaneous laparoscopic surgery was found.
\end{abstract}

Постановка проблеми і аналіз останніх досліджень та публікацій. Жовчнокам'яна хвороба (ЖКХ) є однією з найпоширеніших хірургічних хвороб [1] серед дорослого населення. За даними різних авторів, частота виникнення ЖКХ становить 10-16 \% [2], але в жінок частота даної патології в 4-6 разів вища, ніж у чоловіків. Крім того, у хворих на ЖКХ нерідко зустрічається інша супутня хірургічна патологія [3]. За даними ВООЗ, кількість хворих, у яких діагностується декілька хвороб одночасно і які потребують хірургічної корекції, у різних країнах світу становить до $30 \%[4,5]$.

Щодо лікувальної тактики у хворих на ЖКХ, то вона давно вже визначена, а лапароскопічна холецистектомія (ЛХЕ) є “золотим стандартом” у хірургічному лікуванні [6].

У багатьох пацієнтів поряд з основним захворюванням виявляють супутні хірургічні хвороби (діагностовано паралельно з ЖКХ); вибір хірургічної тактики у таких хворих щодо основного та супутнього захворювання визначаємо як лапароскопічний відповідно до стандартів або алгоритмів чи показань, протоколів тощо.

Технічна зручність виконання симультанних лапароскопічних операцій особливо залежить від правильного вибору точок введення лапаропортів. Ін- траопераційні ускладнення, що виникають внаслідок інтраопераційної технічної незручності, $є$ наслідком неправильної позиції введених троакарів. А тому вирішення проблеми правильного вибору точок введення лапаропортів сприяє швидкому та якісному проведенню і правильному завершенню симультанних операційних лапароскопічних втручань.

Матеріали і методи. Ми провели ретроспективний аналіз 2108 хворих на жовчнокам'яну хворобу, які перебували на стаціонарному лікуванні у відділенні інвазивних методів діагностики та лікування Волинської обласної клінічної лікарні в період 2009-2015 рр. Кількість хворих на жовчнокам'яну хворобу, в яких на момент перебування в стаціонарі було виявлено супутню хірургічну патологію, склала 175 (8,3 \%) чоловік. Із них жінок - 108 (61,7 \%), чоловіків - 67 (38,3 \%).

Кількість прооперованих хворих, у яких разом із ЖКХ було виявлено одну супутню хірургічну патологію органів черевної порожнини, становила 153 (87,4 \%) особи, а кількість прооперованих хворих на ЖКХ із виявленими двома чи більшою кількістю хірургічних патологій - 22 (12,6 \%) пацієнти.

Нозологічно мали поєднання: ЖКХ із грижею стравохідного отвору діафрагми, ЖКХ і кіста печін- 
ки, ЖКХ із кістою підшлункової залози, ЖКХ з кістою нирок, ЖКХ зі злуковою хворобою органів черевної порожнини, ЖКХ і пахова грижа, ЖКХ та двобічна пахова грижа. Операційні втручання виконували в межах верхнього поверху у хворих, що мали поєднання ЖКХ із грижею стравохідного отвору діафрагми, ЖКХ із кістою печінки, ЖКХ із кістою підшлункової залози, ЖКХ із кістою нирок. У хворих з ЖКХ зі злуковою хворобою органів черевної порожнини, ЖКХ і паховою грижею, ЖКХ та двобічною паховою грижею симультанні лапароскопічні втручання виконували в межах двох поверхів.

Детальну структуру пацієнтів основної групи показано в таблиці 1.

Таблиця 1. Структура пацієнтів основної групи

\begin{tabular}{||l|c||}
\hline \multicolumn{1}{|c|}{ Нозологічні поєднання } & Кількість хворих (70 чоловік), n (\%) \\
\hline \hline ЖКХ із грижею стравохідного отвору діафрагми & $61(34,8 \%)$ \\
\hline ЖКХ із кістою печінки & $11(6,2 \%)$ \\
\hline ЖКХ із кістою підшлункової залози & $5(2,9 \%)$ \\
\hline \hline ЖКХ із кістою нирок & $11(6,2 \%)$ \\
\hline ЖКХ зі злуковою хворобою органів черевної порожнини & $56(32 \%)$ \\
\hline ЖКХ і пахова грижа & $23(13,1 \%)$ \\
\hline ЖКХ та двобічна пахова грижа & $8(4,8 \%)$ \\
\hline \hline
\end{tabular}

Нами проведено кропіткий аналіз ходу кожної операції і встановлено таку, на нашу думку, зручну черговість симультанних операційних лапароскопічних втручань, а саме: у хворих із поєднанням ЖКХ з грижею стравохідного отвору діафрагми, ЖКХ зі злуковою хворобою органів черевної порожнини другим етапом виконуємо лапароскопічну холецистектомію. У пацієнтів із ЖКХ і кістою печінки, ЖКХ і кістою нирок, ЖКХ та паховою грижею першою проводимо операцію з приводу ЖКХ. Вивчивши напрям дії сил, які прикладаються до основних робочих інструментів, та напрямок сили опору тканин, віднайшли оптимальне стереометричне співвідношення робочих інструментів при виконанні симультанних лапароскопічних операційних втручань, що дозволяє за рахунок оптимального розташування портів мінімізувати ефект фехтування, покращувати доступність об'єкта операції, зменшувати психоемоційне напруження та фізичне навантаження хірургів.

В основній групі було 175 пацієнтів, із них жінок - 108 (61,7 \%), чоловіків - 67 (38,3 \%). Середній вік хворих становив 52,06 року, наймолодшій пацієнтці було 28 років, найстаршій - 89 років. У 158 (90,3 \%) пацієнтів симультанні захворювання було діагностовано на госпітальному етапі, а в 17 (9,7 \%) хворих наявність симультанного захворювання була встановлена безпосередньо відразу на етапі проведення оглядової або ж діагностичної лапароскопії. Відповідно, у цих хворих рішення про виконання симультанної лапароскопічної операції приймали безпосередньо під час інтраопераційного консиліуму.

У 24 (13,7 \%) хворих основної групи мали місце в анамнезі раніше перенесені операційні втручаня з приводу різної хірургічної патології.

Передопераційне обстеження включало в себе аналіз даних лабораторних методів обстеження (загальний та біохімічний аналіз крові, аналіз сечі, ко- агулограма та ін.), дані інструментального обстеження (УЗД, КТ, ФГДС, ЯМРПХГ та при необхідності деякі інші), а також дані анамнезу та огляду пацієнтів.

Передопераційна підготовка пацієнтів не відрізнялась від загальноприйнятих, лапароскопічні втручання виконували під загальним знеболюванням та з використанням відеокомплексів фірм Karl Storz, Olympus та MGB. Післяопераційне обстеження включало в себе моніторинг загального стану пацієнта в найближчому післяопераційному періоді (ЕКГ, інтенсивність больового синдрому, тривалість перебування в стаціонарі після операції тощо).

Результати, отримані внаслідок виконання симультанних лапароскопічних операцій у вибраних хворих, ми порівнювали з результатами, отриманими у хворих, які перенесли звичайну лапароскопічну холецистектомію.

Результати досліджень та їх обговорення. Лапароскопічна холецистектомія визнана “золотим стандартом” у лікуванні хворих на жовчнокам’яну хворобу [5]. Переваги лапароскопічних хірургічних технологій над традиційними не обговорюються. А твердження про те, що лапароскопічна холецистектомія - це вибір методу операційного лікування, стало аксіомою [6].

Всім хворим проводимо прицільне УЗД обстеження місць введення троакарів на предмет виявлення злукового процесу. Відповідно, карбоксиперитонеум накладаємо за допомогою голки Вереша або за методикою Хассена.

Враховуючи оптимальне співвідношення інструментів, розробили:

- схему розташування робочих інструментів для симультанних операцій у хворих із жовчнокам'яною хворобою та грижею стравохідного отвору діафрагми (рис. 1); 


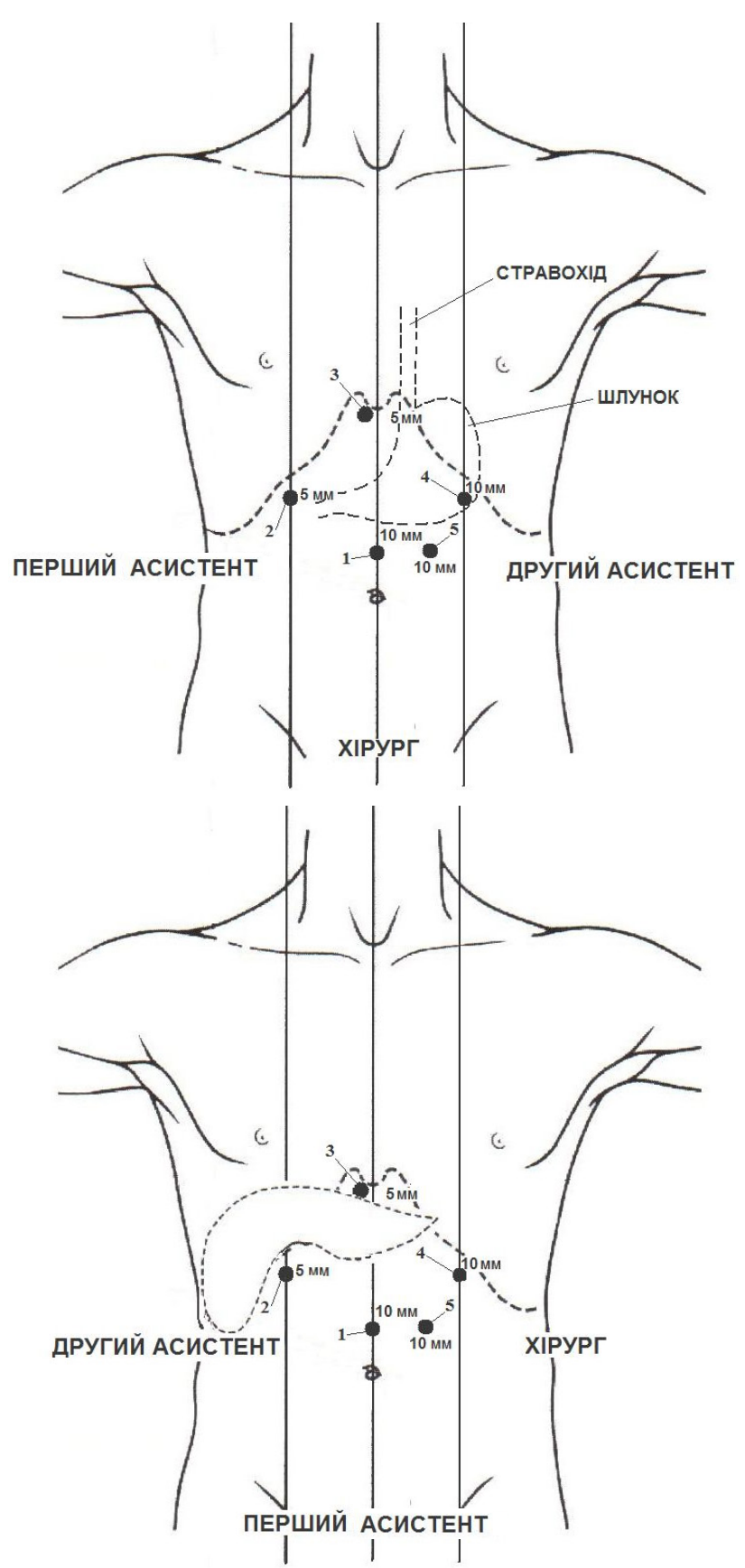

Рис. 1. Схема розташування робочих інструментів для симультанних операцій у хворих із жовчнокам'яною хворобою та грижею стравохідного отвору діафрагми: 1. 10-міліметровий порт для візуалізації черевної порожнини та операційного поля (розміщення лапароскопа); 2. 5-міліметровий порт для тракції лівої частки печінки, а згодом для маніпуляцій з жовчним міхуром; 3. 5-міліметровий порт для маніпуляцій у ділянці стравохідного отвору діафрагми, а згодом основний робочий інструмент при холецистектомії; 4. 10-міліметровий порт для маніпуляцій у ділянці стравохідного отвору діафрагми (для ендостіча), згодом для кліпування кліпатором міхурової протоки та артерії; 5.10-міліметровий порт для маніпуляцій у ділянці кардіального відділу шлунка та для візуалізації при вилученні жовчного міхура.
- схему розташування троакарів у хворих 3 ЖКХ та кістою печінки (рис. 2);

- схему розташування троакарів у хворих 3 ЖКХ та кістою нирки (рис. 3);

- схему розташування троакарів у хворих 3 ЖКХ та кістою підшлункової залози (рис. 4);

- схему розташування троакарів у хворих 3 ЖКХ та злуковою хворобою органів черевної порожнини (рис. 5);

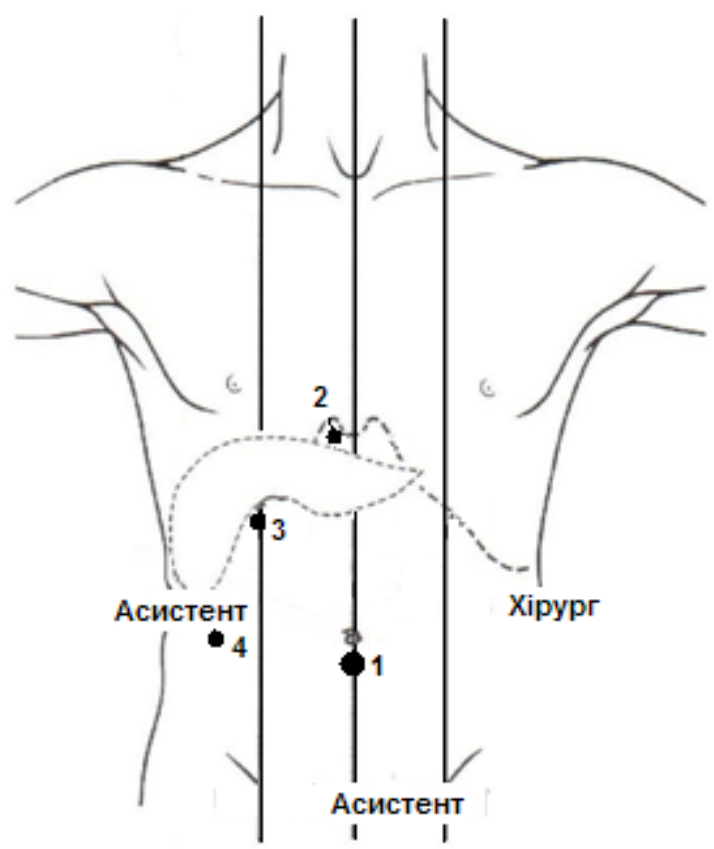

Рис. 2. Схема розташування троакарів у хворих 3 ЖКХ та кістою печінки.

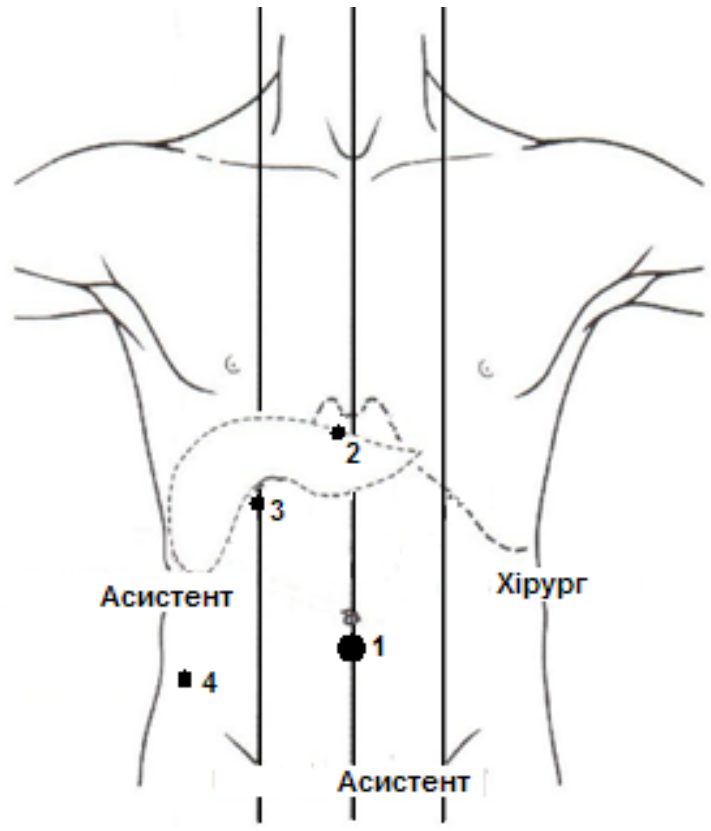

Рис. 3. Схема розташування троакарів у хворих 3 ЖКХ та кістою нирки. 


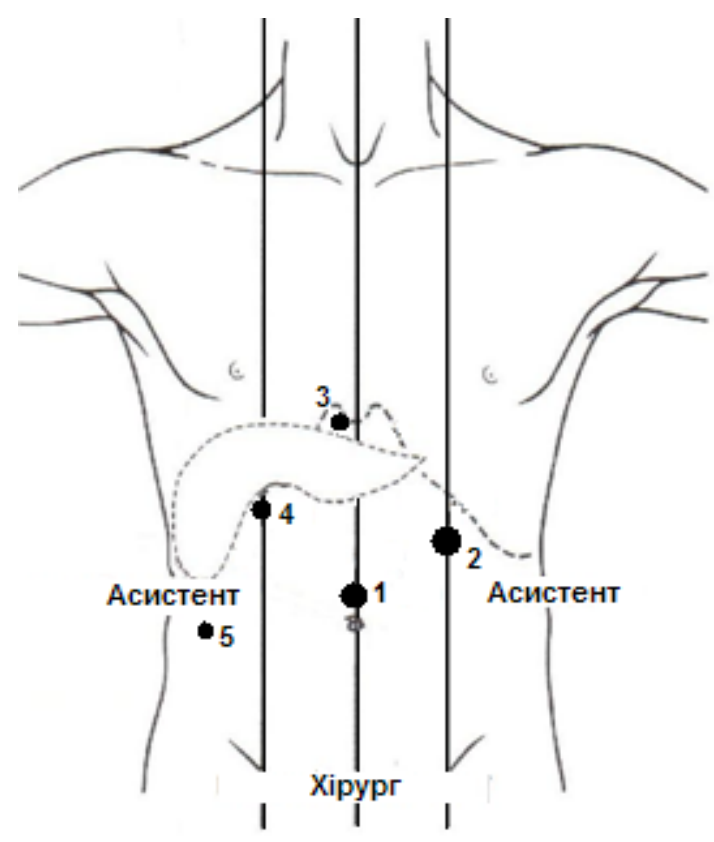

Рис. 4. Схема розташування троакарів у хворих 3 ЖКХ та кістою підшлункової залози.

- схему розташування троакарів у хворих 3 ЖКХ та паховими грижами (рис. 6).

На рисунках візуалізуються базові правила розміщення робочих інструментів для виконання симультанних лапароскопічних операцій для тих комбінацій, що зустрічаються найчастіше. Розміщення хірурга й асистентів, робочих інструментів часто міняється залежно від ситуації.

Як наслідок, частота інтраопераційних ускладнень зменшилась, що відображено в таблиці 2.

Схематично критерії оцінки ранніх післяопераційних результатів відображено в таблиці 3.

Як випливає з наведених результатів, дані аналізу раннього післяопераційного періоду підтвердили:

1. Симультанні лапароскопічні операції незначно або взагалі не впливають на критерії оцінки даного періоду порівняно з хворими, яким було виконано лише лапароскопічну холецистектомію.

2. Різниця в основних показниках перебуває в межах допустимої статистичної похибки.

3. Симультанні лапароскопічні операції $\epsilon$ оптимальними для цієї категорії хворих.

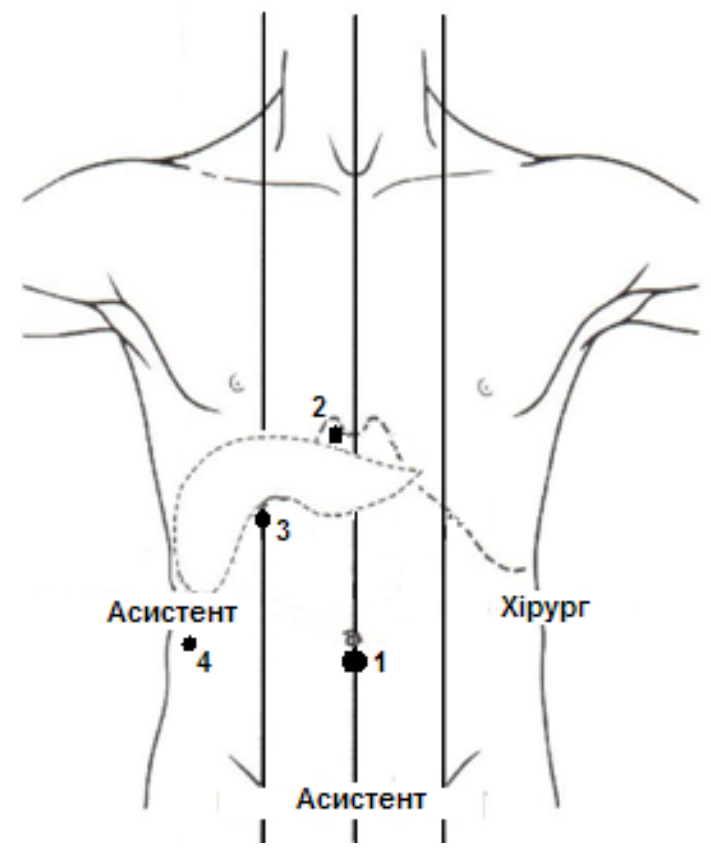

Рис. 5. Схема розташування троакарів у хворих 3 ЖКХ та злуковою хворобою органів черевної порожнини.

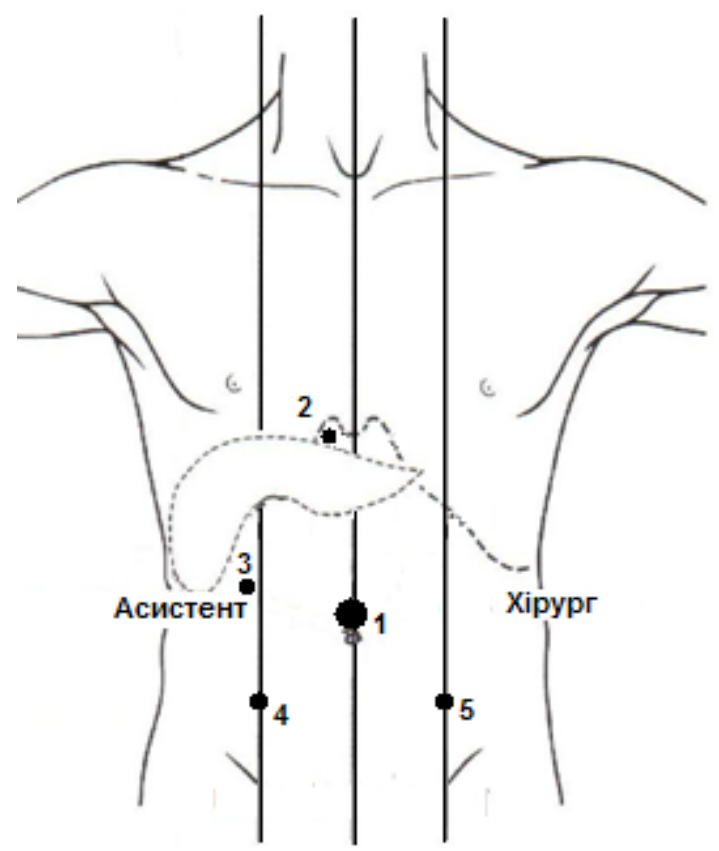

Рис. 6. Схема розташування троакарів у хворих 3 ЖКХ та паховими грижами.

Таблиця 2. Інтраопераційні ускладнення у хворих I групи

\begin{tabular}{||l|c|c||}
\hline \multicolumn{1}{|c|}{ Види ускладнень } & 2009-2012 pp., n (\%) & 2013-2015 pp., n (\%) \\
\hline Внутрішньочеревна кровотеча & $13(7,6 \%)$ & $4(2,5 \%)$ \\
\hline Пошкодження внутрішніх органів & $2(1,1 \%)$ & $0(0 \%)$ \\
\hline Диспозиція кліпса & $6(3,4 \%)$ & $2(1,1 \%)$ \\
\hline $\begin{array}{l}\text { Ускладнення при евакуації препарату 3 } \\
\text { черевної порожнини }\end{array}$ & $2(1,1 \%)$ & $2,1 \%)$ \\
\hline
\end{tabular}


Таблиця 3. Результати Со під час операції та в ранньому післяопераційному періоді

\begin{tabular}{||l|c|c||}
\hline \multicolumn{1}{|c|}{ Критерії } & Основна група I & Група порівняння \\
\hline Тривалість доопераційного обстеження & 1,5 доби & 1,2 доби \\
\hline Тривалість операції & 1 год 05 хв хв \\
\hline Кількість інтраопераційних ускладнень & $11(6,3 \%)$ & $4(3,3 \%)$ \\
\hline Кількість ліжко-днів після операції & 4,8 & 3,5 \\
\hline Інтенсивність больового синдрому & незначна & незначна \\
\hline Частота ранніх післяопераційних ускладнень & $5,6 \%$ & $3,2 \%$ \\
\hline
\end{tabular}

Висновки. 1. Максимально уважний діагностичний пошук дає можливість виявити хворих 3 кількома хірургічними патологіями.

2. Симультанна лапароскопічна операція $€$ методом вибору операційного лікування вище-

\section{СПИСОК ЛІТЕРАТУРИ}

1. Geiger M. Laparoscopic resection of colon cancer and synchronous liver metastasis / M. Geiger, D. Tebb, E. Sato [et al.] // J. Laparoendosc. Adv. Surg. Tech. - 2006. - Vol. 16(1). P. 51-53.

2. Kim H. Laparoscopic-assisted combined colon and liver resection for primary colorectal cancer with synchronous liver metastases: initial experience / H. Kim, B. Lim, H. Ha [et al.] // World J. Surg. - 2008. - Vol. 32(12). - P. 2701-2706.

3. Romero R. Laparoscopic treatment of simultaneous tumors in the liver and kidney / R. Romero, A. Wagner, S. Bagga [et al.] // Urol. Int. - 2007. - Vol. 79(2). - P. 142-144.

4. Infrarenal aortic aneurysm repair by retroperitoneal approach названих захворювань органів черевної порожнини.

3. Оптимальне розташування портів сприяє зменшенню психоемоційного навантаження та фізичного напруження хірургів.

combined with laparoscopic cholecystectomy: two case reports / N. Wolosker, K. Nishinari, B. Ferrari, L. Nakano // J. Laparoendosc. Adv. Surg. Tech. - 2001. - Vol. 11(2). - P. 115-117.

5. Simultaneous Operation of Laparoscopic Fenestration of Hepatic Cyst and Laparoscopic Cholecystectomy / M. Takeyuki, K. Yoshida, S. Kohno, M. Matsuda // Surgical Laparoscopy Endoscopy \& Percutaneous Techniques. - 1994. - Vol. 4(6). P. 497.

6. Laparoscopic hepatic left lateral lobectomy combined with fiber choledochoscopic exploration of the common bile duct and traditional open operation / K. Zhang, S. Zhang, Y. Jiang, P. Gao // World J. Gastroenterol. - 2008. - Vol. 14(7). - P. 1133-1136. 